\title{
Svarte flekker under foten
}
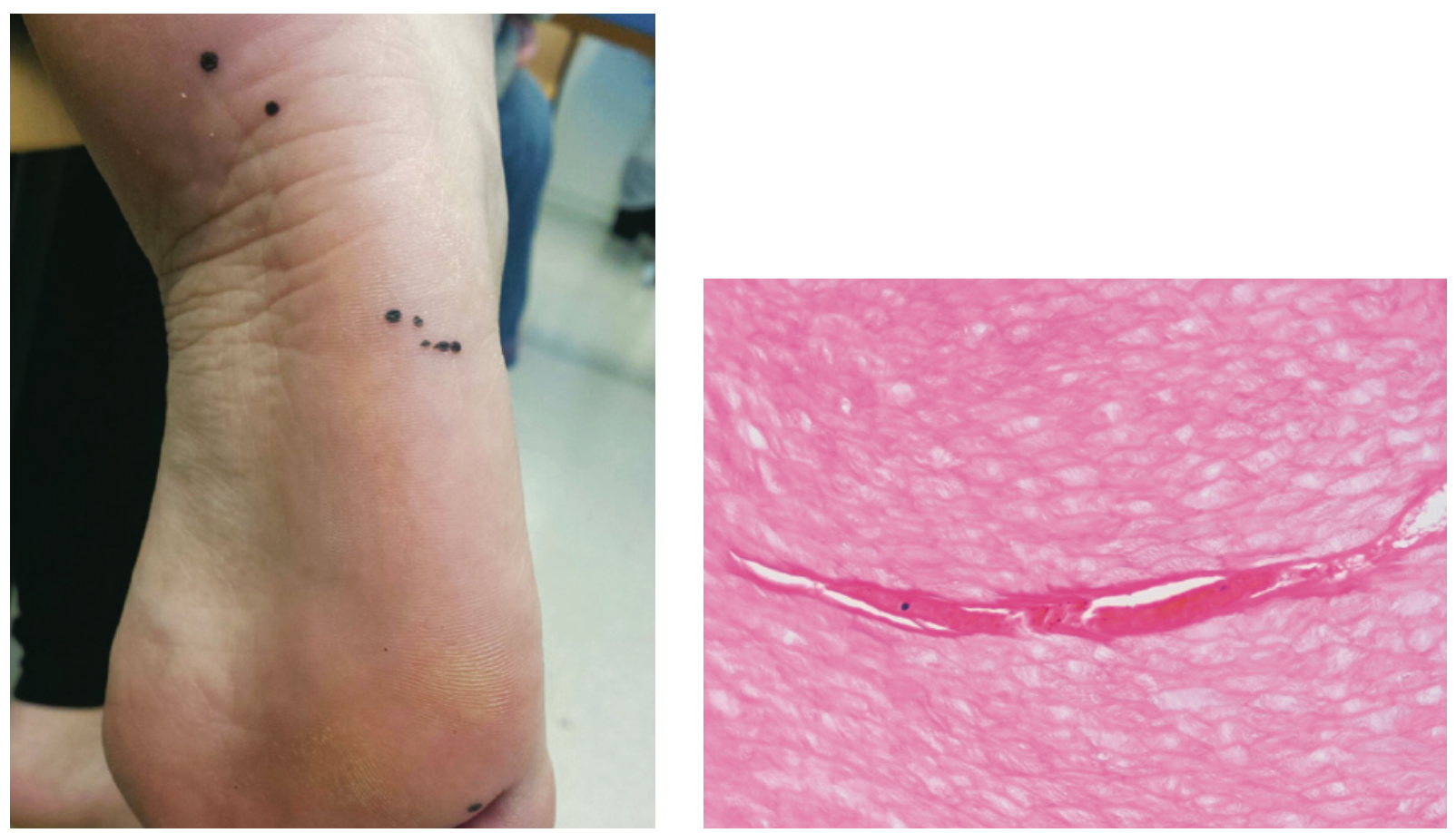

Foto: Stein Helge Røsbekk

En kvinne i slutten av 20-årene, tredjegangsgravid $\mathrm{i}$ annet trimester, uten komplikasjoner, oppdaget svarte flekker på fotsålen. Det ble funnet åtte mørke, makulære hudforandringer med en diameter på $1-5 \mathrm{~mm}$ på den ene fotsålen (bildet til venstre) og en tilsvarende forandring på den andre. Kvinnen følte seg frisk, men hun var plaget av bekkenløsning og hadde derfor fătt endret gangmønster. Hun oppga også at hun hadde hatt usedvanlig høy fysisk aktivitet den siste tiden, men hun hadde ikke deltatt $\mathrm{i}$ idrett.

Mikroskopisk undersøkelse av stansebiopsi viste små områder med lys til mørk brun pigmentering i stratum corneum (hornlaget). Mikroskopibildet er farget med hematoksylin og eosin og viser en rift i stratum corneum med ekstravaserte røde blodceller samt mørke partikler, forenlig med nedbrytningsprodukter fra hemoglobin. Perls' farging bekreftet jernholdige nedbrytningsprodukter av hemoglobin. Øvrige deler av epidermis samt dermis var normale. Diagnosen ble derfor posttraumatiske plantare petekkier.

Slike hudforandringer ble første gang beskrevet i 1961 hos basketballspillere under navnet «calcaneal petechiae» og er senere funnet hos flere typer idrettsutøvere (1-3). Alternative termer er «talon noir» og «posttraumatic punctate haemorrhage of the skin». Tilstanden kan oppstå når trykkpunkter blir utsatt for gjentatt belastning som gir intraepidermal blødning og derfor mørke hudforand- ringer. Histologisk vil man finne områder med pigment og ekstravaserte røde blodceller i stratum corneum samt hemoglobin og nedbrytningsprodukter av dette, og sistnevnte kan påvises ved spesialfarginger for jern (4).

Vi kjenner ikke til tidligere beskrivelser av posttraumatiske plantare petekkier i Norge, ei heller beskrivelse av tilstanden hos gravide. Det er allikevel sannsynlig at dette er vanlige hudforandringer. En undersøkelse av 596 tyske idrettsutøvere viste en insidens på 2,9\% (5). Posttraumatiske plantare petekkier er helt ufarlig. De forsvinner spontant i løpet av noen uker dersom man avlaster trykkpunktene, noe som også skjedde i dette tilfellet.

Pasienten har gitt samtykke til at artikkelen blir publisert.

\section{Björn Logi Isfoss}

isfoss@mac.com

Avdeling for patologi

Sykehuset Telemark Skien

\section{Stein Helge Røsbekk}

Rjukan legesenter

\section{Erling Ekerhovd}

Fertilitetsavdelingen Sør

Sykehuset Telemark Skien

Björn Logi Isfoss (f. 1956) er ph.d., spesialist i patologi og overlege.

Forfatter har fylt ut ICMJE-skjemaet og oppgir

ingen interessekonflikter.
Stein Helge Røsbekk (f. 1980) er fastlege. Forfatter har fylt ut ICMJE-skjemaet og oppgir ingen interessekonflikter.

Erling Ekerhovd (f. 1958) er dr.med., spesialist i fødselshjelp og kvinnesykdommer og overlege.

Forfatter har fylt ut ICMJE-skjemaet og oppgir ingen interessekonflikter.

\section{Litteratur}

1. Crissey JT, Peachey JC. Calcaneal petechiae. Arch Dermatol 1961: 83. 501.

2. Mailler-Savage EA, Adams BB. Skin manifestations of running. J Am Acad Dermatol 2006; 55 290-301.

3. Tlougan BE, Mancini AJ, Mandell JA et al. Skin conditions in figure skaters, ice-hockey players and speed skaters: part I - mechanical dermatoses. Sports Med 2011; 41: 709-19.

4. Weedon D. Reactions to physical agents. I: Weedon D. Skin pathology. 2. utg. London: Churchill Livingstone, 2002: 595

5. Rufli T. Hyperkatosis haemorrhagica. Hautarzt 1980; 31: 606-9.

Mottatt 21.2. 2015, første revisjon innsendt 8.4. 2015, godkjent 29.4. 2015. Redaktør: Lise Mørkved Helsingen. 